\title{
THE ROLE OF FAITH IN A SOCIAL STRUGGLE USING THE EXAMPLE OF THE PASTORAL LETTER OF THE SLOVAK BISHOPS OF NOVEMBER 1924
}

\author{
RÓBERT A R P Á ̌́
}

\begin{abstract}
ARPÁŠ, Róbert. The Role of Faith in a Social Struggle Using the Example of the Pastoral Letter of the Slovak Bishops of November 1924. Historický časopis, 2019, 67, 5, pp. 839-849, Bratislava.

The social movement that developed in Slovakia after the end of the Great War succeeded in capturing the left-wing parties - Social Democracy and the Communist Party. In particular, communists in the ideological struggle did not hesitate to use the alleged parallels of communist ideas with Christianity. Thanks to this tactic, they were also successful among religious populations. Therefore, efforts to establish Christian-oriented trade unions in Slovakia were not too successful. Thus, in November 1924, through the Pastoral Letter, the Slovak bishops entered the conflict and watched with concern the rising anticlerical movement in Czechoslovakia.
\end{abstract}

Keywords: Pastoral Letter. Slovakia. Ideological conflict. Trade unions. Social interests.

DOI: https://doi.org/10.31577/histcaso.2019.67.5.3

After the end of the war and establishment of the new Czechoslovak state, there was also a revolutionary atmosphere on the political level. The Social Democrats were the clear winners of the first Czechoslovak election, namely the local government elections in the Czech Lands in June 1919. ${ }^{1}$ A similar scenario was repeated in April 1920 in the first parliamentary election. ${ }^{2}$ This led to Andrej

1 The Czech Left gained almost half the votes, with the Czechoslovak Social Democratic Labour Party getting $32.5 \%$ and the Czechoslovak Socialist Party $17.3 \%$. The clerically oriented Czechoslovak People's Party got only 9.8\%. The Social Democrats even got a better result among the German population. A total of $47.9 \%$ of the population gave them their votes. Statistická přiručka republiky Československé. (Statistical handbook of the Czechoslovak Republic). Praha: Státní úrad statistický, 1920, p. 103. Local government elections were not held in Slovakia because of the struggles against the Hungarian Soviet Republic and Slovak Soviet Republic.

2 In the first Czechoslovak parliamentary elections, the Social Democrats repeated their victory in the local government elections from 15 June 1919. The Czechoslovak Social Democrats gained $25.65 \%$ of the votes in the whole state. However, it is necessary to add the $11.12 \%$ who voted for the German Social Democrats. The Leftist camp was also strengthened by the Czechoslovak Socialists with their $8.08 \%$ of the votes. The joint list of candidates of the Czech and Slovak clericals with $11.29 \%$ of the votes again fell behind the Left. The results for 
Hlinka chairman of the clerical - conservative oriented Slovenská l'udová strana - Slovak People's Party, known as the L'udáks, making his well-known statement that he would work without ceasing until "red Slovakia became white, Slovak, Christian Slovakia". His mission was already hindered in 1921 by the origin of an even more radical leftist party based on the Bolshevik ideology: the Communist Party of Czechoslovakia. The Communists also took over the themes of socialist propaganda, which used chiliastic elements to spread their ideological principles. At first the Bolshevik agitators behaved extremely sensitively towards the very religious inhabitants of Slovakia. To increase the chance that the ideas of the new worldview would be accepted in the Slovak countryside, they were instructed to avoid attacks on religion. They diplomatically avoided this question or even tried to point to parallels between the teachings of Jesus Christ and the ideological principles of Bolshevism. ${ }^{3}$

However, a political struggle was also occurring in the social field, in the form of a struggle over trade union organizations defending the interests of the working population. The trade unions were closely connected with specific political parties so political struggles directly concerned them. The leftist parties - the Social Democrats and their more radical fellow-travellers the Communists - had an organizational head-start in the field of trade union activity in Slovakia. However, the Slovak People's Party also strove to create its own trade union organization. The split with the Czech Catholics significantly complicated this process, and so in 1923 the Slovak Catholics began the formation of their own trade union movement practically from the beginning. ${ }^{4}$ This delay made it

the clericals in Slovakia looked even worse. The Social Democrats unambiguously defeated them in the ratio $38.05 \%: 17.77 \%$. ŠUCHOVÁ, Xénia. Prílohy II. - Politický systém. (Supplements II - Political System). In ZEMKO, Milan - BYSTRICKÝ, Valerián (Eds.). Slovensko v Československu (1918 - 1939). Bratislava: Veda, 2004, p. 553-554. ISBN 802240795X.

3 For further details on the use of religious elements by leftist parties see BENKO, Juraj. Socialistická ideológia v konfrontácii s religióznym slovenským prostredím v prvej štvrtine 20. storočia (Politizácia krest’anskej tradície a sakralizácia socialistickej vízie). (The socialist ideology in confrontation with the Slovak religious environment in the first quarter of the 20th century (Politicization of the Christian tradition and sacralization of the socialist vision).). In ŠUCHOVÁ, Xénia (Ed.). Ludáci a komunisti: Súperi? Spojenci? Protivnici? Bratislava: HÚ SAV; Banská Bystrica: Katedra histórie FHV UMB; Prešov: Universum, 2006, p. 9-23. ISBN 808904638X.

4 For further information on the formation of the Slovak Catholic trade unions see KATUNINEC, Milan. Slovenské krest’anské odborové hnutie v sociálnom dialógu a konfrontácii. (The Slovak Christian trade union movement in social dialogue and confrontation). In Forum Historiae, 2015, year 9, no. 2, p. 73-78. ISSN 1337-6861. The Czechoslovak authorities carefully watched the dispute between the Christian trade unions. The original leading representative of the Ludák trade union association, member of partliament Jozef Vrabec unsuccessfully appealed for assistance from the gendarmes in a conflict over office space. Národní Archiv České republiky (hereinafter NA ČR) Praha, fond (hereinafter f.) Presidium ministerstva vnit- 
difficult to find members for their trade union organizations. Even very religious Slovak workers had already become members of the functioning organizations associated with the leftist parties, which promised to defend their social interests.

In November 1924 the Slovak Catholic bishops actively intervened in the struggle to regain influence among the Slovak working class in favour of the Slovak Ludáks. Appealing to the strong religious feelings of the Slovak people and representing the authority of the Church, they strongly warned people against membership of left oriented societies. Remaining in them without justification was considered a sin preventing the religious participation of the given person. The bishops also strongly opposed the new attempt to separate Church and state, as well as the efforts to limit the influence of the Church in education. ${ }^{5}$

A wave of opposition to the pastoral letter arose from the leftist camp, which organized protest actions in many places. However the state authorities also had reservations towards the content of the document. According to their legal view, it satisfied the requirements for several criminal offences, especially $\S 14$ sub-section 3 of the Act on Defence of the Republic no.50/1923 Col., which prohibited public incitement of hatred for religious reasons ${ }^{6}$ and $\S 1$ of the Act against Oppression and to Defend Freedom of Assembly no. 309/1921 Col. This legislative norm aimed to prevent persons "such as officials, teachers, clergy or employers" misusing their positions to illegally coerce the citizen to "do, avoid or collect something". 7 The Ministry of the Interior developed activities aimed at preventing reading of the letter in churches, ${ }^{8}$ but it had already been published. For example, on 28 December 1924 it was also published in the Slovák newspaper of the People's Party. Representatives of the state administration expressed surprise that it had not been censored. In spite of its publication, the authorities carefully monitored priests who read it in their churches. ${ }^{9}$ The campaign against the Slovak clergy with which the state reacted to the bishops' letter already led in January 1925 to the Czech and Moravian bishops expressing solidarity with their

ra - Archiv ministerstva vnitra (hereinafter PMV-AMV) 225, škatul'a (box) (hereinafter š.) 256, signature (hereinafter sig.) 225-256-1.

5 Slovák, 28 December 1924, p. 1-2, Duchovná správa a protikrest’anské sdruženia. (A spirtual report on anti-Christian association.).

6 Sbírka zákonů a nařízení státu československého, (Collection of acts and decrees of the Czechoslovak state), part 23, Praha 31 March 1923, p. 210, Zákon ze dne 19. března 1923 na ochranu republiky (Act on defence of the republic from 19 March 1923).

7 Sbírka zákonů a nařízení státu československého, part 71, Praha 6 Sept 1921, p. 1254, Zákon ze dne 12. srpna 1921 proti útisku a na ochranu svobody ve shromážděních (Act against oppression. and in defence of freedom of assembly from 12 August 1921).

8 NA ČR Praha, f. PMV-AMV 225, š. 355, sig. 225-355-16.

9 NA ČR Praha, f. PMV-AMV 225, š. 355, sig. 225-355-16. 
Slovak brothers, "who had done their duty and used their rights when publishing their pastoral letter". ${ }^{10}$

An investigation was also launched to uncover the initiators of the document. According to the findings of the state institutions, the main author was Bishop Augustín Fischer-Colbrie of Košice. ${ }^{11}$ On the other hand, Bishop Marian Blaha of Banská Bystrica allegedly had a reserved attitude to it. ${ }^{12}$ The authorities strove to use Fischer-Colbrie's authorship in attempts to get him removed from his position as bishop. They had observed him with dissatisfaction for a long time and recorded in detail his pro-Hungarian thinking and negative attitude to the Czechoslovak state. They even considered the possibility of deporting him to Hungary.$^{13}$ However, that struck against the position of the Vatican with which Czechoslovakia was engaged in complex negotiations to achieve a modus vivendi. ${ }^{14}$ The dispute on the person of the Bishop of Košice was ended by his sudden death, when he succumbed to illness on 17 May $1925 .{ }^{15}$

The text of the pastoral letter is given in its original form as it was published in the censored edition of the Slovák daily no. 270 from 28 December 1924 on the title page and half the following page.

* The paper originated in the framework of the grant VEGA no. 2/0054/17 Cultural Infrastructure of the Czechoslovak State School Policy and its Realization in Slovakia. (The Link between Educational Activities of School System with The Educational and Schooling Influence on Population), researched at the Institute of History of the Slovak Academy of Sciences and is an output from the project APVV (Slovak Research and Development Agency) no. 17-0199 The Cultural Product of Regional Museum in Context of the Objective Social Needs: Life in Totalitarianism 1939-1945 researched at Constantine the Philosopher University in Nitra.

10 NA ČR Praha, f. PMV-AMV 225, š. 356, sig. 225-356-1. The Papal Nuncio Francesco Marmaggi appealed for the Czech and Moravian bishops to support their Slovak colleagues. HRABOVEC, Emília. Slovensko a Svätá stolica 1918 - 1927 vo svetle vatikánskych prameňov. (Slovakia and the Holy See 1918-1927 in the light of Vatican sources). Bratislava: Univerzita Komenského v Bratislave, 2012, document 58, p. 418. ISBN 8022332279.

11 NA ČR Praha, f. PMV-AMV 225, š. 355, sig. 225-355-16.

12 NA ČR Praha, f. PMV-AMV 225, š. 355, sig. 225-355-16.

13 NAČR Praha, f. PMV-AMV 225, š. 355, sig. 225-355-16.

14 Relations between Czechoslovakia and the Holy See were also strained by a renewed effort to enact separation of Church and state, weakening of Church influence over education, and proposed legislation on new state holidays, which reduced the number of religious holidays while introducing a new holiday dedicated to Ján Hus. On tension in Czechoslovak - Vatican relations, see, e.g. HRABOVEC, ref. 10, p. 73-78.

15 For further information on the life of Bishop Fischer. Colbrie see e.g. MIHÓKOVÁ, Mária. Košický biskup ThDr. Augustín Fischer-Colbrie 1863 - 1925. (The Bishop of Košice ThDr. Augustin Fischer-Colbrie 1863-1925). Košice: Verbum, 1996, 72 pages. ISBN 8096695754. 


\section{A spiritual report on anti-Christian associations!}

\section{Dear Believers!}

Our paternal heart has long been troubled by the sad fact that many of you, dear believers, have thrown yourselves in recent years into the embrace of associations that not only endanger your eternal salvation, but also your justified material well-being.

During the terrible storm of war, the rough sea of passion blunted the soul and moral feeling declined. A feverish desire for quick repair exploded on the first rainbow of peace into regrettable actions in places. Long cultivated and in many ways disappointed hopes have angered and torn the whole community, leading it into extraordinary confusion. The fog of desperate uncertainty covered the whole horizon, and lies in hearts and minds like a strong wall. Vices have the effect of somebody drowning or grasping a razor.

Various dishonourable adventurers exploited the difficult position to hunt in the turbid conditions. Calculating the advantages of leadership and abundant profit they stood at the head of the poor and organized them. They succeeded. Excellent promises and enticing slogans drew to them crowds of people, who thought little but dreamed a lot about the post-war paradise they hopefully awaited.

But did this beautifully drawn and promised paradise arrive?

Maybe for the false prophets themselves, but not at all for the deceived crowds!

It is impossible to hide that a vigorous united approach and strong solidarity have gained the serving and working classes a temporary improvement of their material position, but soon they will find themselves in an even worse slavery than before. Do we not already hear from many sides about the modest slice of bread that used to satisfy them? Crowds of the unemployed and poor call for work and some shelter.

The new false gospel and the associations formed on its basis have not succeeded. They have failed. We cannot expect redemption from them in the future either, as the example of Russia shows. Its principles have been fully put into practice there and with what result? Poverty such as the world has never heard of before! Who would not be shaken to the entrails and who would not weep tears of sympathy at the desperate moan of a once so great and glorious brother nation? How many valiant hearts and how many skilful heads fell in the recent famine in that naturally rich and fertile country? And how many more would 
have fallen if the international community and especially the gloriously reigning Holy Father Pius XI ${ }^{16}$ had not taken an interest in Russia and supplied food for millions? Those withered, paralysed hands of the dead, which also reached out for help but in vain because it did not reach them, are raised up in eternal testimony that the teachings of the false prophets, who gained control of them are not true. Material poverty is not avoided with satanic pick-axes, but only increased. A tree is known by its fruit. (Mat. 12,33)

But more terrible than physical death and shortage is the devastation of souls caused by the new errors, as will be considered further below.

If the organizers of the suffering poor unprofitably support the removal of the wrongs that liberalism reared and over-saturated capitalism inflicted; if they sincerely care that economic conflicts are justly settled; if they honourably fight for every field, not only their own but also for those they have around them; if they self-sacrificingly work and not only talk about the healing of unhealthy relations in the family, society and the state: who would be more willing to join them and offer a helping hand than we ourselves? Sadly, however, we very often find that those who present themselves as the greatest defenders of the oppressed and clearly paint liberty, equality and fraternity, do the most to undermine the foundations and pillars of all justice, love and peace: namely faith and morality. We are convinced that they would like to take out of the world the most caring mother and benefactor of suffering humanity, the eternal guardian and spreader of mercy, truth and justice, from Christ the Lord, namely us the Catholic Church. How could we not protest against it? Can shepherds fail to be vigilant while wolves are destroying their herd? The words of the Saviour also apply to them: "They come to you in sheep's clothing, but inside they are fierce wolves." (Mat. 7, 15).

They are working very carefully. To gain adherents, they paint real and invented wrongs with pharisaical refinement and apparent participation in suffering. They flatter with errors of pre-disposed desire of the body, eye and pride of life to stimulate endless dissatisfaction. They also support their coating of plausibility and weight of evidence with the name of Jesus Christ and the words of Holy Scripture just as the tempter - the devil did before (Mat. 4, 3-11). They also struggle to terrify even religiously inclined listeners, stressing that they are not against religion. Allegedly it is a private matter for each person and they will not interfere. But gradually, inconspicuously and indirectly, their speeches and writings oppose everything connected with religion. They ridicule, devalue and deny the teachings and institutions of the Church. They devalue the Creed, Ten Commandments, sacraments and everything considered sacred by our forebears and ourselves. In the name of alleged science and progress, they oppose the Lord

16 Pius XI was Pope $1922-1939$. 
God himself and devalue him with their dirty mouths and hideous publications as if he were only a childish fable meaning nothing. To them, man is only a perfected animal descended from apes. Marriage is not a sacrament, but only a civil contract. They do not recognize eternal rewards and punishments: because they leave like one of their leaders - Bebel - he said to angels and sparrows. Private property is foreign to their vision. Although it was gained honourably by blood and calluses, they declare it theft.

And what about the highest law: love for neighbour? Do they not kick it away when instead of understanding and moderation they proclaim class war, violence, terror and revolution?

Their attitude to Christianity is shown by their wish to push it out of every sphere of private and public life. To get the Church out and secularize everything is their slogan. What does that mean in simple language if not to secularize and paganize? They would like to deprive the Church of everything, taking even the last halier (the smallest coin) so that the disabled serving woman or abandoned beggar would seek refuge in catacombs. Who has not heard about separation of Church and state or secularization? They do not want religious education and curse Church schools as is clear. They would not like to see the cross and catachism or anything that recalls and preserves the memory of supernatural faith even among the junk preserved in a private storeroom at home.

It is understood that they go for anybody who opens his mouth against them to obstruct their insidious plans. So do not be surprised that the clergy are a red rag to them, as targets they like to blacken, discredit and drag into the mud. None of these real or alleged misdemeanours from the past or present are forgotten, but exaggerated and placed on the neck of priest, monk or nun. For them, the clergy are only sleazy wasters or hedonists, who allegedly do not care for the hungry crowd, and are the enemies of the poor. But we know that the truth strikes the eyes and who is in the oven thinks that they are all. "Strike at the shepherd and disperse the sheep" (Zach. 13, 7).

Can you wonder, dear faithful, that when a wretched person hears and reads nothing from day to day except that religion and its bearers are against his justified interests, he becomes estranged from it and becomes opposed to it? Why should his conscience trouble him when his financial and other contributions to public life strengthen the anti-religious current?

It is true that the majority of those associated with the new errors still outwardly participate in religion and perform their liturgical duties. But are there unfortunately, already some among the common people, who are entirely cut off from the heritage of their fathers and who openly fight against the Church? And how many blindly gave their trust to non-believers in spite of the rosary in their hands and a lot of religious talk? 
The ranks of the fighters are growing. How to excuse oneself before God? Let us not be confused! The Saviour says: "Nobody can serve two masters. Either he will hate one and love the other, or he will adhere to one and scorn the other." (Mat. 6, 24). Is it possible to have one foot in heaven and the other in hell? Can one hand be stretched out to God and the other to Satan? Can the Arc of the Covenant and the Philistine god Dagon be placed on the same altar (1 Kings 5, 2 and following)? Can somebody cooperate with the Synagogue of the crucifiers of the Lord Jesus and with his immaculate bride the Church and still be regarded as a true follower of Christ and faithful child of the Church? A vain excuse! Judas, the eternal traitor sold our Saviour for a large sum! Something may be as useful as a hand, a foot or an eye, but according to the teaching of Jesus, if it leads you into mortal sin, you must be determined and get rid of it. (Mark 9, 2) Are excellent rewards of wealth, comfort and pleasure offered to martyrs for being struck down? "For what does it profit a person to gain the whole world if he loses his soul? What price can a person be given in exchange for his soul" asks Christ the Lord. (Mat. 16, 26)

Understand us well, dear faithful! We are far from being against you using all morally permissible means to achieve a more tolerable and more comfortable life. On the contrary, we consider it our duty to support you in this effort. We only appeal to you and protest that unconscientious selfish adventurers should not lead you with honeyed cords out of the mud and into the swamp. We indulge you, that you are like roses and more often blessedly smile: You are our children and we are your parents in Christ. Aware, however, of our terrible responsibility before the court of the just, almighty and all-seeing God "as such who have to give the number of your souls" (Hebrews 13,17), we cannot allow that, with or without bread, you consume the fatal poison and perish.

Therefore, following the example of the Dutch, German and Swiss bishops, with love, but firmly and strictly, we issue the following directive informing our clergy and you that you will know what to observe:

It is forbidden for a Catholic Christian to be a member of an anti-Christian society of any name or branch. As anti-Catholic societies, we must clearly include not only all the anarchist and nihilist groups, but also various socialist and communist associations. Everybody also knows that the Free Masons are also against the life of the Church.

When Catholics have the possibility to establish social class associations, which do not oppose religion, they are obliged to leave the anti-Christian trade unions.

A registered Catholic can be allowed to temporarily remain in an anti-Christian organization only under the following four conditions:

If the member sincerely thought when he joined that this was allowed; 
When it is provable that only a membership payment can defend the essentials of subsistence, he is under so much pressure from the fear that in the opposite case he would be driven from work, factory, office or service; but otherwise he promises that he will do everything possible to avoid contact with the organization, and will not go to meetings and speeches, will never read or allow others to read, so that their civil trust and voice do not go over to the anti-Christian side;

If his temporary membership does not expose his family to the danger of falling away from the faith.

A Catholic Christian who was sufficiently informed about these rules, and who could have left the anti-Christian association, but maliciously remains in it, is an unrepentant sinner and renegade who cannot be admitted to the holy sacraments or be given any rights or respect in the Church he has betrayed. Even absolution in the sacrament of penance is not enough and if - God forbid - he dies in this sin, he cannot have a Church funeral. Similarly with honourable actions and Church positions such as godfather, legal adviser and so on, because they belong only to faithful Catholics.

When, like the bishops in other countries, we declare this, we are only doing our duty from which we cannot deviate regardless of any entreaties or threats.

We force no-one, we do no violence, we do not persecute. Everyone decides for himself whether to remain with Christ or with Beelzebub!

The reverend clergy and all true believers rightly expect that we should prove ourselves gloriously and decisively. We have done so. We want only glory for God and peace for people of good will (Luk. 2, 14).

Our Saviour said very sharply and without packaging: "Do not give dogs what is sacred; do not throw your pearls to pigs. If you do, they may trample them under their feet, and then turn and tear you to pieces." (Mt. 7, 6.)

What is more sacred than faith, what is more valuable than the immortal soul?

The holy season of Advent renews in us the memory of the coming of the Saviour of the world. He came as the good shepherd of his sheep. He himself emphasizes the difference between him and the seducer of souls, when he says: "The thief comes only to steal and kill and destroy; I have come that they may have life, and have it to the full. I am the good shepherd. The good shepherd lays down his life for the sheep." (John 10, 10-11.)

Let us see how the good sheep obey the voice of their shepherd! Let us endeavour to rescue them from sin and from all the errors that are the seedbed of sin! And from temptation, so that we do not get entangled again! May the grace and mercy of our Lord Jesus Christ embrace you all, may he enlighten and correct the sinful and maintain the good of the just! Amen!

Žilina, 26 November 1924. 
+ Augustin, ${ }^{17}$

Bishop of Košice.

+ Jan, ${ }^{18}$

Bishop of Spiš.

+ Peter, ${ }^{19}$

Bishop of Munkačevo ${ }^{20}$.

Dr: Pavel ${ }^{21}$ Jantausch, ${ }^{22}$

Apostolic Administrator of Trnava.

$+\mathrm{Karol}^{23}$

Bishop of Nitra.

+ Marian, ${ }^{24}$

Bishop of Banská Bystrica.

+ Dionys, ${ }^{25}$

Bishop Apostolic Administrator of Prešov.

Dr. Stefan Podraczký, ${ }^{26}$

Vicar of the Chapter of Rožňava.

Abrahám Táhy, ${ }^{27}$

Episcopal Vicar of Užhorod.

17 Augustín Fischer-Colbrie became Bishop of Košice in 1907. He was the only bishop in Slovakia not expelled from the republic after the formation of Czechoslovakia. He remained in office until his death in 1925.

18 Ján Vojtaššák was one of the first three Slovak bishops appointed by Pope Benedict XV in 1920. He was consecrated as bishop in the following year. After the Second World War he was arrested and convicted because of his activities in the Slovak Republic of 1939-1945. The Vatican refused to remove him from his position as bishop as the Czechoslovak government requested. He officially remained bishop until his death in 1965.

19 Peter Gebej acted as bishop of the Greek Catholic Eparchy of Mukačevo in the period 1924-1931.

20 The name should be Mukačevo but has been influenced by Latin munkacsiensis.

21 The spelling "Pavol" is also used.

22 The Pope appointed him as Apostolic Administrator of Trnava in 1922. He became a bishop in 1925 and remained Apostolic Administrator of Trnava until his death in 1947.

23 Karol Kmet'ko was appointed bishop in 1920 at the same time as Ján Vojtaššák and Marian Blaha. He was consecrated as a bishop in 1921. In 1944 Pius XII appointed him Archbishop ad personam. He remained in office until his death in 1948.

24 Marian Blaha headed the Diocese of Banská Bystrica from his appointment by the Pope in 1920 until his death in 1943.

25 Dionýz Nyáradi was entrusted with administration of the Diocese of Prešov in 1922. He remained Apostolic Administrator of Prešov until 1927, when he returned to his home state Yugoslavia.

26 He was Vicar of the Chapter of Rožňava from 1920 to 1926.

27 Parish priest of Užhorod and Apostolic Administrator of the Czechoslovak part of the Diocese of Satu Mare (in Hungarian: Szatmár) until his death in 1934. 
DIE AUFGABE DES GLAUBENS IM SOZIALEN KAMPF AM BEISPIEL DES GEISTLICHEN BRIEFES DER SLOWAKISCHEN BISCHÖFE VOM NOVEMBER 1924

\section{RÓBERT A R P Á S̆}

In der sozialen Bewegung, die sich in der Slowakei nach dem Ersten Weltkrieg entwickelte, konnten sich vor allem die linke Parteien - die Sozialdemokratie und die aufstrebenden Kommunisten durchsetzen. Insbesondere die Kommunisten zögerten im ideologischen Kampf nicht, die angeblichen Parallelen zwischen der kommunistischen Lehre und dem Christentum zu nutzen. Dank dieser Taktik waren sie auch unter religiöser Bevölkerung erfolgreich. Dies ist auch einer der Gründe, warum die Bestrebungen um Gründung christlich orientierten Gewerkschaften in der Slowakei scheiterten. Die slowakischen Bischöfe schauten der antiklerikalen Bewegung in der Tschechoslowakei besorgt zu und sind dann im November 1924 mittels eines Hirtenbriefes in den Konflikt eingetreten.

PhDr. Róbert Arpáš, Ph.D.

Historický ústav SAV

Ďumbierska 1, 97411 Banská Bystrica

Katedra histórie FF UKF

Hodžova 1, 94974 Nitra

e-mail: arpas@savbb.sk 